\title{
Actual monetary policy independence in a small open economy: the Polish perspective
}

\author{
Lukasz Goczek ${ }^{1}$ • Dagmara Mycielska ${ }^{1}$
}

Received: 11 May 2015 / Accepted: 9 November 2017 / Published online: 22 December 2017

(C) The Author(s) 2017. This article is an open access publication

\begin{abstract}
The aim of this article is to examine the actual degree of monetary policy independence in a small open economy with floating exchange rate that is integrated with the world economy. It is frequently argued that for such a country the primary cost of participation in a currency area is the loss of monetary policy independence. The article raises the question if the proposition of monetary independence provided by floating exchange rate applies to a small open economy, operating within highly liberalised capital flows and highly integrated financial markets. We examine the actual degree of monetary policy independence in Poland using a vector error correction mechanism model and the data for the years 2001-2014. We obtain evidence pointing to the lack of such independence, and we show that this result is robust to extensive changes in specification, including impulse saturation.
\end{abstract}

Keywords Small open economy $\cdot$ Monetary policy independence $\cdot$ Monetary union · Poland

JEL Classification E43 - E52 - E58 - F41 - F42 - C32

\section{Introduction}

The assumption of monetary policy independence in an open economy with floating exchange rates lies at the heart of most analyses concerning the effects of the

\footnotetext{
$凶 \quad$ Łukasz Goczek

lgoczek@wne.uw.edu.pl

Dagmara Mycielska

dmycielska@wne.uw.edu.pl

1 Faculty of Economic Sciences, University of Warsaw, ul. Długa 44/50, 00-241 Warsaw, Poland
} 
European Monetary Union (EMU). Numerous studies of monetary policy independence, which are based on the now classical concepts of "impossible trinity" and theory of optimum currency areas, argue that the primary long-run cost of participation in a common currency area is the loss of independence of monetary policy.

Monetary policy independence is understood as the ability of the central bank to set interest rates independently of international rates (Aizenman et al. 2013). This can be questioned especially in terms of small open economies with highly integrated financial markets. Let us consider the case of an interest rate shock in the larger monetary area that would lead to deviation between its interest rate and the rates of a small open economy. This would lead to depreciation in the small open economy in the absence of interest changes. However, this depreciation is costly both in terms of balance sheet effects and inflation. These factors should be incorporated into the small open economy's central bank loss function, which would give the monetary authority of the small open economy an incentive to use the interest rate to carry out the adjustment instead of allowing its currency to depreciate. Under these conditions, a monetary authority in the small open economy may not enjoy monetary independence even under a more flexible exchange rate regime because it lacks credibility.

This credibility could be particularly low if the economy is highly integrated financially with a larger monetary area such as the dollar or the euro area because an interest rate deviation could lead to a relatively high volume of financial flows that could destabilise the small economy. Thus, the central bank has no choice but to change interest rates in response to changes in the monetary policy of a leading country-probably the country with the largest financial market in the regionto avoid differences in interest rates causing large capital flows and exchange rate volatility (Ehrmann and Fratzscher 2002). Di Giovanni and Shambaugh (2008) suggest that the interest rates are the channel of transmission through which the large country's monetary policy influences smaller markets. Frankel et al. (2004) show that countries with flexible exchange rates experience full transmission of world interest rates. Some authors, for instance Taylor (2007), Hofmann and Bogdanova (2012), or Rey (2016) even go as far as to say that interest rate dependence applies to large economies, and prior to the financial crisis the European Central Bank (ECB) was not carrying out an independent monetary policy stance but was merely copying the decisions made by the US Federal Reserve Bank (the Fed).

We analyse whether monetary policy in the focus economy-Poland — was 'determined' abroad-that is, if it was largely influenced by the policies of the larger monetary area. The reasons for this are related to increasing integration with the Eurozone and external conditions. The first explanation is growing business cycle correlation between Poland and the Eurozone. In this sense, the adoption of foreign interest rates can be seen as a result of increased economic integration through trade and financial markets, which resulted in the synchronisation of business cycles, as suggested by the endogenous theory of optimum currency areas (see Frankel and Rose 1998). Therefore, monetary policy convergence will increase with trade and capital links between these areas. 
Another possible cause might be a common component of global inflation; in such cases the central banks of both regions react in the same way to disturbances that are exogenous to their decisions. The high degree of similarity in policies between the domestic and foreign central bank is therefore a reflection of not so much a lack of independence in an institutional sense, but rather of the symmetry of shocks affecting the domestic and foreign economies.

The lack of monetary independence could in fact be a manifestation of the fearof-floating phenomenon in Poland. The ability to conduct an independent monetary policy in a country characterised by a fear-of-floating exchange rate is limited because management of interest rates may be in fact reduced to an implicit exchange rate management tool.

However, all of these causes of lack of monetary policy independence lead to the same effect; in a positive sense, the monetary policy in the smaller country will not be independent.

The main hypothesis of the article is that Poland currently has very little de facto independence in monetary policy, and the changes in the Polish monetary policy are largely a consequence of the monetary policy changes led by the European Central Bank. This has important policy implications. This actual lack of monetary policy independence in small open economies with highly integrated financial markets would imply that Poland does not lose this independence during accession to the EMU, as this cost has already been borne.

The main hypothesis of the paper is verified using cointegration testing of nominal interest rates in Poland and the EMU. Based on the results of cointegration testing, the vector error correction mechanism (VECM) model has been constructed. The model is used to test several parametric hypotheses concerning the speed and asymmetry of adjustment between interest rates in Poland and the EMU that allow for the causality to be determined between monetary policies of both currency areas.

The first part of this article presents a literature review of monetary independence in small open economies. The second part describes the empirical strategy and parametric hypotheses that are verified using the VECM model. The third part presents the results concerning historical relationships between interest rates in Poland and the EMU. The fourth part provides a discussion of the robustness of the results. The article concludes with a discussion of policy implications of the results in the context of Poland's joining the Eurozone. The research presented in this paper is an attempt to complement the existing state of the art in the field of economic research on the benefits and costs of Poland's adoption of the euro. Therefore, the investigation of the de facto independence of monetary policy and exchange rate conditions has fundamental consequences for assessing the effects of introducing the euro as a legal tender in Poland.

\section{Literature review}

A central result in international macroeconomics is the policy trilemma (Obstfeld et al. 2005): if a country has a credible fixed exchange rate and is open to international financial flows, its interest rate must follow that of the anchor country, which 
implies sacrificing monetary independence. If not, an increase in the anchor country's interest rate that is not matched by an increase in the domestic country's rates would lead to investors shifting funds to assets denominated in the higher interest rate currency, which generates depreciation of the exchange rate. Thus, monetary autonomy requires that a country must either allow the exchange rate to float or restrict international capital movement (Klein and Shambaugh 2013). However, it could be argued that there is no convincing empirical evidence to support the assertion of a link between exchange rate flexibility and monetary independence because the policies of small open economies with integrated capital markets are generally not credible.

Rey (2016) argues that we tend to think in line with the trilemma. Therefore, in a financially integrated world, fixed exchange rates export the monetary policy of the centre country to the periphery and the corollary is that if there are free capital flows, it is possible to have independent monetary policies only by having the exchange rate float; thus, the floating exchange rates enable monetary policy independence. The author, however, questions whether the scale of financial globalization put even this into question. Are the financing conditions set in the global financing centres setting the interest for the rest of the world, regardless of the exchange rate regime?

Hausmann et al. (2001) find that interest rates in countries with floating exchange rate regimes are as dependent on and responsive to US monetary policy shocks as are those countries with fixed currency regimes. Frankel (1999) examines a broad sample of countries and also fails to detect a strong link between exchange rate flexibility and interest rate autonomy. Edwards (2015) analyses whether countries with flexible exchange rates from Latin America are able to pursue an independent monetary policy, as suggested by traditional theory. His results allow him to argue for a significant "policy contagion," and that these countries tend to "import" Fed policies.

Ball and Reyes (2008) analysed the problem of the fear of floating in inflation targeting countries. They show that because of fear of floating the volatility of interest rates is higher than the changes in inflation and appears to be strongly associated with exchange rate volatility. These results are not sensitive to the existing exchange rate regime, which confirms empirically the lack of independence of monetary policy in a country characterised by the fear of floating. The occurrence of the fear-of-floating phenomenon is confirmed by the results obtained by D'Adamo (2010) and van Dijk et al. (2011). European countries that have not adopted the euro show a higher volatility (pursuing the inflation targeting policy), but it is not as high as in other non-European countries. It seems that a certain weight in monetary policy is given to the stability of the exchange rate against the euro. Moreover, van Dijk et al. (2011) show that the correlation between the exchange rates of the main EU countries outside the euro area against the dollar and the euro rose after the introduction of the euro. Countries outside the area may wish to keep the exchange rates of their currencies stabilised to the euro, which results in lower exchange rate volatility, without a definite need for a full abandonment of independent monetary policy. However, de facto independence of monetary policy in a country characterised by the fear of floating will be limited as such policy will not be credible. 
Those findings contradict the predictions of the classical concept of the impossible trinity. Floating exchange rates do not necessarily indicate the independence of monetary policy. In this context, it could be questioned even if larger economies such as Italy, the Netherlands, or France had any independence from the interest rates set by the Bundesbank before monetary unification. Reade and Volz (2011) analysed relationships between the interest rates of European countries prior to EMU creation. The results support the conclusion that the actual loss of monetary independence could refer exclusively to Germany. Other European countries that joined the EMU could not lose what they did not have.

Buscher and Gabrisch (2011) performed similar analyses for Sweden, Denmark and the UK. The study confirmed the presence of a high level of correlation between short-term Euribor rates and short-term interbank interest rates in these countries. The authors confirmed the existence of this dependence not only in times of peace but also in times of disturbances, indicating that the ECB's policy has a significant impact on the domestic interest rates and, therefore, monetary policy independence cannot be indicative of the benefits of staying outside the euro area. Using the cointegrated VAR, Reade and Volz (2010) show that the market interest rates in Sweden are correlated with the Euribor rates, and monetary policy in Sweden is largely a copy of the decisions made by the ECB.

The possible loss of monetary policy independence is being indicated as the main cost of monetary integration for Poland (NBP 2009). Gradzewicz and Makarski (2009) tried to estimate the possible cost of losing monetary policy independence by using a simulation study based on the DSGE model. However, the study assumes de facto independence of Polish monetary policy, but this assumption has not been tested. D'Adamo (2009) argues that Poland belongs to a small group of inflation targeting countries that has shown exchange rate volatility over the last 10 years, which is comparable to the variability of the exchange rates of benchmark country currencies from the sample. However, tests for foreign reserves volatility have shown that after the introduction of the euro volatility of foreign exchange reserves increased significantly in all countries in the sample (the same goes for Poland). The estimated coefficient between the change in exchange rate and the change in reserves is positive and stable for most countries of the region, and the importance attached to stability in relation to the euro is not clearly defined, but estimated to be somewhere between 0.4 and 0.5 . This again suggests a lack of full independence in conducting monetary policy in the countries staying out of the EMU. On the other hand Baranowski and Gajewski (2015) find Polish monetary policy fully credible. This result is, however, limited to forward guidance period in Poland.

Polish monetary policy independence was also analysed in Cuaresma and Wojcik (2006). The authors investigate a DCC-MGARCH model of real interest rates in Germany and three eastern European economies and conclude that these countries do not enjoy monetary policy independence. Moreover, they have shown that in the case of Poland the increase in flexibility of the exchange rate regime went hand in hand with the correlation between interest rates in Poland and Germany, which is contrary to the Mundell-Fleming paradigm. It is necessary to note, however, the limited and dated choice of the studied period. The investigation was carried out using data that span the period of 1994-2002. In contrast, the exchange rate of Polish zloty was officially 
floated in mid-2000, so the period of most significant interest spanned less than two years. In addition, the use of a large number of dummy variables could potentially render some of the conclusions less strong.

On the other hand, Windberger et al. (2012), while analysing different methods of estimating the volatility of interest rates and exchange rates, conclude that Poland has had a significant degree of monetary independence in the last decade. The data span the period starting from 2002, but the authors include structural breaks in their model to obtain estimates that are more reliable. However, the procedure for choosing the timing of those breaks is unclear. The authors also do not discuss the diagnostic problems, which we found to be relevant for weekly frequency of interest rates in the case of Poland.

\section{Empirical methodology and specification}

Let us consider the following Uncovered Interest Parity (UIP) condition:

$$
i_{t}=i_{t}^{*}+E_{t}\left(e_{t+1}-e_{t}\right)+\rho,
$$

$i$ is the domestic nominal interest rate, $i *$ is the foreign nominal interest rate, $E$ is the expectation operator, $e$ is the nominal exchange rate, $\rho$ is the risk premium, and $t$ is the time index.

Moving (1) into first differences, we obtain:

$$
\Delta i_{t}=\Delta i^{*}+\Delta E_{t}\left(e_{t+1}-e_{t}\right)+\Delta \rho,
$$

where $\Delta$ is the difference operator.

In a fixed exchange rate regime, the exchange rate is constant, and the depreciation term becomes zero. Assuming that the risk premium does not affect the change in interest rates and the expected future exchange rate remain the same, the domestic interest rate moves one on one with the foreign rate change, that is, there is a full transmission of foreign interest rates:

$$
\Delta i_{t}=\Delta i_{t}^{*}
$$

According to the target zone models, the interest rates may diverge persistently under a flexible exchange rate regime only if the domestic policies are credible and the monetary authority primarily targets domestic economic variables such as inflation and output. Therefore, the size and the length of the deviation can be used to measure the degree of monetary policy independence. This may be interpreted as the degree to which domestic interest rates follow international interest rates. If a steady-state relationship exists between interest rates in the two monetary areas, and furthermore, one country adjusts to this relationship while the other does not, then this is the evidence in favour of monetary dependence of the adjusting country on the non-adjusting one.

Interbank interest rates are the most appropriate measures of the monetary policy stance in two currency areas (Bernanke and Blinder 1992). If domestic interbank 
interest rates react to changes in the domestic monetary policy stance according to expectations, this means that this country enjoys a large degree of monetary policy independence. If, however, interbank interest rates react mostly to foreign interest rate changes or if the two economies are intricately linked, as dictated by close movements of their three-month interbank interest rates, it is unlikely that domestic monetary policy exerts much independence. An alternative to this approach would be the use of the reference rates of the relevant central banks. These variables, however, change very infrequently and show low variance. Moreover, it could be argued that these do not take into account market expectations; however, most importantly, it could be that the central bank does not have any policy effectiveness despite setting its reference interest rates relatively far from the interest rate parity. Hence, interbank interest rates provide an effective means for investigating monetary policy independence and, based on the above listed reasons, it could be argued that the measures of interest rates chosen for the empirical model estimated in the article are indeed appropriate. Based on this conclusion, in this empirical analysis 3-month Wibor and Euribor interest rates are used during the period 2001-2014 (after the floatation of PLN and joining the EU by Poland) with daily, weekly and monthly frequency.

The data-generating process for interest rates is commonly accepted to be integrated of order one according to the empirical literature on interest rates, even though it might not be plausible from a theoretical economic viewpoint. This result was also found in our data. Even so, the treatment of processes close to non-stationarity as non-stationary in the econometric approach is more appropriate and less harmful than acting upon a theoretical economic consistency. ${ }^{1}$

Let us consider two time series for domestic and international interest rates that form a bivariate data vector $X_{t}$ given by:

$$
\mathbf{X}_{t}=\left(\begin{array}{l}
i \\
i^{*}
\end{array}\right)_{t}
$$

The domestic interbank interest rate (Wibor_3M) is denoted by $i_{t}$, and the international interbank interest rate (Euribor_3M) is denoted by $i_{t}^{*}$. The two variables are used to form a vector autoregressive (VAR) model described by the following equation:

$$
\mathbf{X}_{t}=\Pi_{0}+\Pi_{1} t+\sum_{i=1}^{K} \Pi_{i} \mathbf{X}_{t-i}+\mathbf{u}_{t}
$$

where the error term $\mathbf{u}_{t} \sim N\left(0, \sigma^{2}\right)$ is uncorrelated over $t$, the data vector $\mathbf{X}_{t}$ is $p \times T$ dimension, $K$ is the number of lags, and $\Pi_{i}$ is the deterministic coefficient matrix (constant and trend) of a dimension $p \times p$. If the data generation process is nonstationary in levels and stationary in first differences, then Eq. (5) can be rearranged to form a vector error correction mechanism:

1 See Moon and Perron (2007). 


$$
\Delta \mathbf{X}_{t}=\Pi^{*} \mathbf{X}_{t-1}^{*}+\sum_{i=1}^{K-1} \Gamma_{i} \Delta \mathbf{X}_{t-i}+\mathbf{u}_{t}
$$

where $\mathbf{X}_{t-1}^{*}=\left(\mathbf{X}_{t-1}, 1, t\right)^{\prime}, \Pi^{*}=\left(\Pi, \Pi_{0}, \Pi_{1}\right), \Pi=\sum_{i=1}^{K} \Pi_{i}-I$ and $\Gamma_{i}=$ $-\sum_{j=i+1}{ }^{K} \Pi_{j}$. For the ease of exposition the coefficients for the lagged regressors and the deterministic terms were grouped together, which is similar to the taking of this problem in most econometric packages. Under the assumption that $\mathbf{X}_{t} \sim I$ (1) and $\mathbf{u}_{t} \sim I(0)$, the matrix $\Pi$ is of reduced rank for Eq. (3) to be balanced. If $\Pi$ is of reduced rank, then there exists $p \times r$ matrices $\alpha$ and $\beta$ such that $\Pi=\alpha \beta^{\prime}$ and Eq. (3) can be transformed to a form taking into account the decomposition of long-run coefficients:

$$
\Delta \mathbf{X}_{t}=\alpha \beta^{\prime} \mathbf{X}_{t-1}^{*}+\sum_{i=1}^{K-1} \Gamma_{i} \Delta \mathbf{X}_{t-i}+\mathbf{u}_{t} .
$$

The term $\beta^{\prime} \mathbf{X}_{t-1}^{*}$ is the cointegrating vector ${ }^{2}$ showing the steady-state relationship between the interest rates. In the context of interest rates those are linear combinations, which themselves are non-stationary, but the relationship between them is stationary with a steady-state cointegrating vector forming uncovered interest rate parity.

If the matrix $\Pi$ is of rank one, it means that a single cointegrating vector exists, and $\beta^{\prime}$ is $1 \times p+2$ (constant and trend in the cointegrating relationship). The cointegrating vector can then be rewritten as follows:

$$
\beta^{\prime} \mathbf{X}_{t-1}^{*}=\left(\beta_{0}, \beta_{1}, \beta_{2}, \beta_{3}\right)\left(\begin{array}{l}
1 \\
t \\
i_{t} \\
r_{t}^{*}
\end{array}\right)=\beta_{0}+\beta_{1} t+\beta_{2} i_{t}+\beta_{3} i_{t}^{*}
$$

If it is found during the empirical analysis of the two interest rates that the rank is indeed one, this means that there exists a single cointegration vector-a single steady-state relationship. This is an indication of monetary policy dependence in the currency areas. However, it could be argued that this relationship does not have bilateral causality or feedback properties. From a theoretical viewpoint, it is very probable that Poland's target zone is not credible enough for domestic interest rate deviation from the international rates to hold over prolonged periods because the Polish economy is integrated financially and economically with the Eurozone. In contrast, an opposite relationship is quite unlikely to hold; it seems impossible that Polish interest rates influence the interest rates of the currency area orders of enormity larger than the Polish economy. This corresponds to the weak exogeneity of Eurozone interest rates.

The properties of these relationships can be verified using a parametric test concerning coefficients from the matrix $\alpha$. The statistical significance and the sign of the $\alpha$ coefficients indicate how a given interest rate reacts to disequilibrium from the cointegrating vector. This means that it is possible to indicate which of the interest rates adjusts to the other, at what speed and to what degree. In the analysed case, it is

2 Under the condition that $\Pi$ is of a reduced rank. 
therefore expected that the Wibor rate changes towards the steady-state relation with the Euribor and Euribor is weakly exogenous. This is testable through the hypothesis that the adjustment coefficient is insignificant in the Euribor equation and significant in the Wibor equation.

The specification of the cointegrating equation allows for the analysis of the steadystate equilibrium holding between the interest rates in both currency areas. It is expected that the interbank market in the smaller currency area will exhibit a higher risk premium. This hypothesis can be verified by testing the sign and significance of the intercept in the cointegrating equation. At the same time, it could be argued that because of Poland's expected entry into the EMU and the intensifying financial integration of Poland into European capital markets since the early 1990s, this premium is expected to fall. This should be observed in the long-run convergence of the two interest rates. This phenomenon can be measured using the linear trend term coefficient in the cointegrating equation.

Summing up the argument - the parametric hypotheses can be outlined as follows:

1. $\mathrm{H}-{ }_{0}: \Pi$ is of rank one-there exists a long-run steady-state relationship between the interest rates in Poland and the Eurozone.

2. $\mathrm{H}_{0}: \beta_{0} \leq 0$-test of the existence of a positive risk premium in Poland.

3. $\mathrm{H}_{0}: \beta_{1}=0$-no long-run convergence in risk premium between the two areas.

4. $\mathrm{H}_{0}: \alpha_{1}<0$-limited monetary independence in Poland, adjustment to the steadystate relationship with the Eurozone.

5. $\mathrm{H}_{0}: \alpha_{2}=0$-weak exogeneity of euro interest rates: no adjustment of Euribor to the interest rates in Poland.

6. $\mathrm{H}_{0}: \beta_{1}=-1$-total homogeneity-the interest rates move jointly in a one-by-one fashion and if equilibrium is disturbed by a movement in a country's interest rate, then the smaller country's interest rate must move by the same amount to restore equilibrium.

\section{Empirical model results}

As a first step, the unit root tests were run to check the stationarity of the time series in the bivariate data sample. In this context, the unit root presence was verified using standard unit root tests and tests allowing a structural break in the stochastic process. ${ }^{3}$ The authors determined that the stochastic processes of all of the investigated series are integrated of order one at the 5\% level of significance. This was again confirmed for the analysed data.

The next step was to develop an unrestricted vector autoregressive (VAR) model to determine the optimal number of lags using information criteria separately for all three data frequencies. The Schwarz information criterion (SIC) has pointed to two lags as the optimal number. Moreover, the lag exclusion testing provided the result that all of the lags are significantly different from zero.

Subsequently, the Johansen cointegration test was performed in its three versions: choosing rank based on trace statistic, the maximum eigenvalue and the minimisation

3 Using ADF, KPSS, Ng-Perron and Zivot-Andrews tests. 
of an information criterion. All three methods are based on the Johansen's maximum likelihood estimator of the parameters of a cointegrating VECM, with different cointegrating equation assumptions and data trends specifications. During verification, the economic-theoretical meaning of each type of assumption was taken into account, which relates to the six hypotheses given earlier. A positive intercept in the cointegrating equation relates to a positive risk premium in the smaller country over the larger economy. The trend term relates to the expectations that Poland's participation in the EMU should manifest itself in long-run interest rate convergence. This should be observable in the long-run fall of the interest rate risk premium in Poland (as argued in Goczek and Mycielska 2016). These results in various specifications are summarised in Table 1.

In all analysed cases, except for the assumption of a quadratic trend in the data, the selected number of cointegrating equations was equal to one. The case of quadratic trend should be rejected, however, both under theoretical considerations and due to statistical results pointing towards no trend in the data. As in the lag-length selection problem, choosing the specification of the cointegration equation that minimises either the Schwarz information criterion (SIC) or the Akaike information criterion (AIC) provides a consistent estimator of the steady-state equilibrium. Of the two criteria SIC was the preferred measure. Table 2 summarises the results. Based on them it can be concluded that there exists a single long-run cointegrating relationship. Furthermore, it was determined that there exists an intercept in the cointegrating equation without a trend term.

Table 3 presents the results of the Johansen tests. Regardless of the data frequency, the results are highly statistically significant. This evidence is overwhelmingly in favour of a steady-state relationship between Wibor and Euribor. ${ }^{4}$ The obtained $P$ value for the hypothesis that there is no cointegration is at most 0.0001 for monthly data. The obtained $P$ value for the hypothesis that there is at most one cointegrating equation ranges from 0.73 in monthly data to 0.99 in daily data. This test outcome is very conclusive and it is unlikely that any size distortions in the trace test could have affected the test enough to bias this particular outcome. At this point it can be argued that there exists a long-run steady-state relationship between the interest rates in Poland and the Eurozone, and thus, monetary policy in Poland is not independent. This confirms the first hypothesis of the article.

Based on the above results, a VECM model was constructed to estimate the level of dependence of domestic interest rates on international ones. VECM was specified without an intercept in VAR and a constant in the cointegrating equation (no trend). Next, the AR Roots of the characteristic polynomial were calculated to determine whether the VECM model was stable. All roots except one lie inside of the unit circle. This is not of a concern because the error correction mechanism assumed in the VECM model imposes one unit root.

More diagnostic tests followed. The results of LM autocorrelation test showed different autocorrelation order of residuals for each data frequency. To tackle this problem, the number of lags in the VECM models has been increased over the SIC

4 Rank test is robust to ARCH effects. 


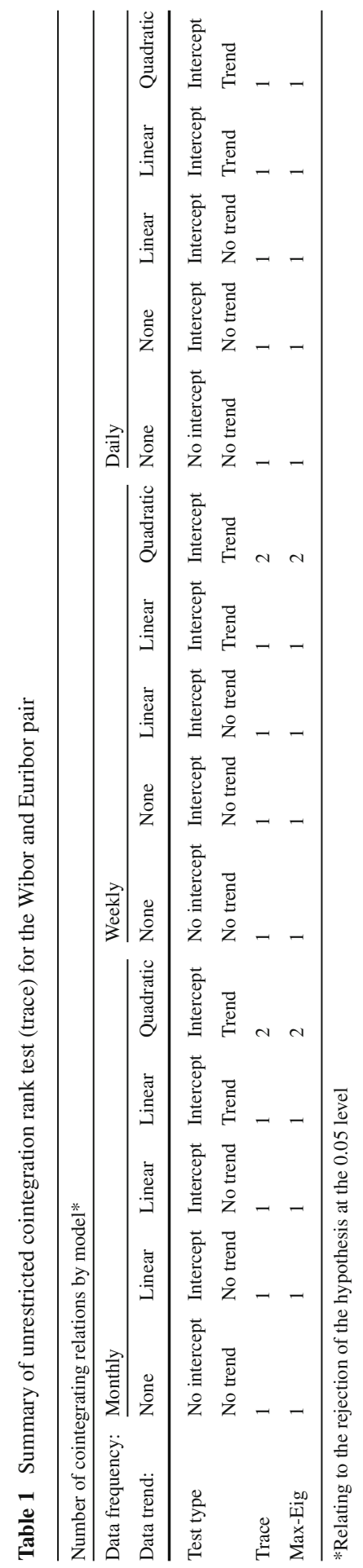




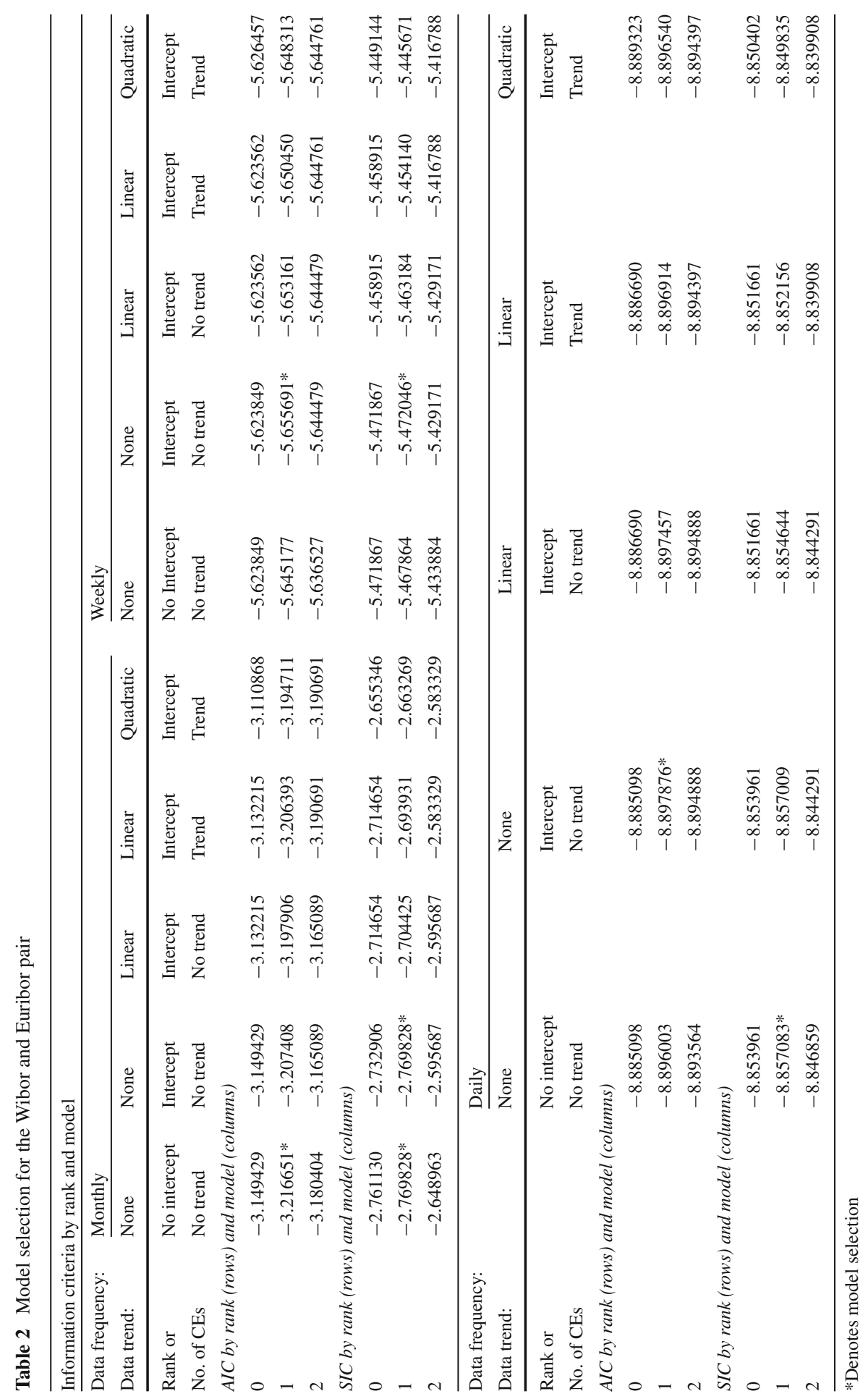




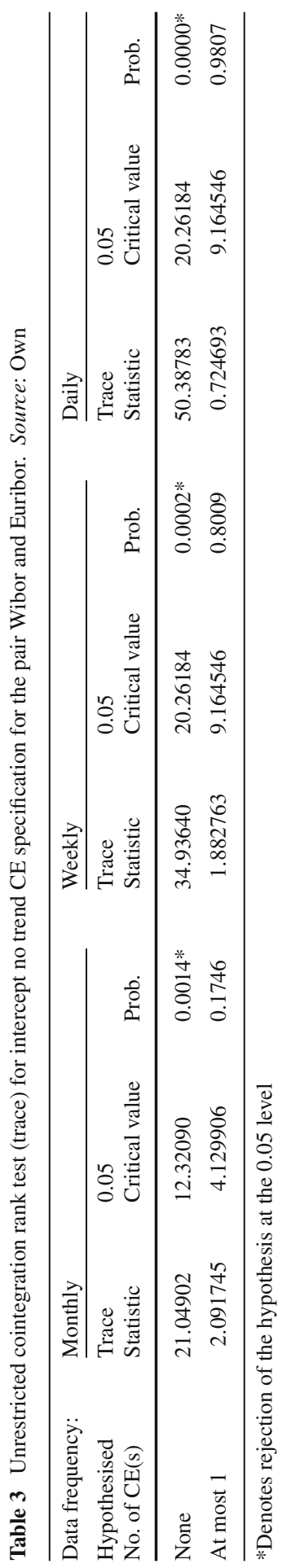


Table 4 VECM models for the Wibor and Euribor pair. Source: own

\begin{tabular}{|c|c|c|c|c|c|c|}
\hline \multicolumn{2}{|l|}{ Data frequency } & \multicolumn{2}{|l|}{ Monthly } & \multicolumn{2}{|l|}{ Weekly } & Daily \\
\hline$\beta_{3}$ & & -0.853305 & & -0.729910 & & -0.922274 \\
\hline \multirow[t]{2}{*}{ (Euribor) } & & $(0.23840)$ & & $(0.27422)$ & & $(0.26045)$ \\
\hline & & {$[-3.57934]$} & & {$[-2.66175]$} & & {$[-3.54110]$} \\
\hline \multirow[t]{4}{*}{ Error correction: } & $\begin{array}{l}\alpha_{1} \\
\text { (Wibor) }\end{array}$ & $\begin{array}{l}\alpha_{2} \\
\text { (Euribor) }\end{array}$ & $\begin{array}{l}\alpha_{1} \\
\text { (Wibor) }\end{array}$ & $\begin{array}{l}\alpha_{2} \\
\text { (Euribor) }\end{array}$ & $\begin{array}{l}\alpha_{1} \\
\text { (Wibor) }\end{array}$ & $\begin{array}{l}\alpha_{2} \\
\text { (Euribor) }\end{array}$ \\
\hline & -0.077904 & -0.006481 & -0.008950 & -0.001101 & -0.002547 & -0.00008 \\
\hline & $(0.01806)$ & $(0.00574)$ & $(0.00159)$ & $(0.00054)$ & $(0.00036)$ & $(0.00008)$ \\
\hline & {$[-4.31335]$} & {$[-1.12843]$} & {$[-5.61353]$} & {$[-2.03097]$} & {$[-7.06496]$} & {$[-0.95875]$} \\
\hline
\end{tabular}

Standard errors in (), $z$ statistics in [ ], the CE vector is normalized to zero resulting in a negative sign for the positive relationship

criterion, mostly at hand with the Akaike criterion, the exception being daily data. The models of the final form included 10,38 and 12 lags, respectively, for monthly, weekly and daily frequencies. The final specification results for different data frequencies are shown in Table 4.

The constant term in the cointegrating equation is positive. This points towards positive risk premium associated with investing in Poland. A model with the trend term was also run to verify the hypothesis of long-run convergence in interest rate and diminishing risk premium, even though this specification was not selected under the above specification selection procedure. Nevertheless, this approach generally failed because the trend term in the cointegrating equation proved to be insignificant. This allows us to conclude that there are no grounds to reject the hypothesis that there is no long-run convergence in risk premium between the two areas.

The estimated coefficient on Euribor suggests that the increase in this variable by one percentage point causes an increase in Wibor by $0.73-0.92$ percentage point. That would suggest that the transmission of international rates onto Wibor is not full; however, the value of a one-to-one transmission lies within the confidence interval for all data frequencies and this gives no grounds to reject the null hypothesis of a full transmission of foreign interest rates.

The overall adjustment speed is significant only for the Wibor rate, meaning that only the Polish rates adjust to the relation, while Euribor rates do not. The estimates for the alpha term relating to the speed of adjustment to the long-run relation differ quite markedly for each data frequency. The results suggest that, with the exception of the marginal significance for the weekly data, the weakly exogeneity of Euribor cannot be rejected. Thereby, we give more weight to the results for monthly data for interest rates that should portray the long-run relationships.

Based on the above results, it can be concluded that the empirical verification has brought the following results:

1. There exists a long-run steady-state relationship between the interest rates in Poland and the Eurozone.

2. There exists a positive risk premium for investing a Poland. 
3. There are no grounds to reject the hypothesis of no nominal interest rate convergence between Poland and the Eurozone. The risk premium for investing in Poland does not diminish in a steady state.

4. The results allow us to argue that the degree of monetary independence in Poland is low and that Polish interest rates adjust to the changes in interest rates in the Eurozone for a given disequilibrium to the steady state.

5. As expected, Euribor is weakly exogenous and Eurozone rates do not depend on changes in monetary policy in Poland.

6. The hypothesis of a one-to-one relationship between Polish and Eurozone interest rates cannot be rejected.

\section{Robustness}

It should be stressed that the model selection was based on econometric theory. During these selections, models with the most conservative predictions were selected. Most of the rejected models have shown a much higher degree of Polish monetary policy dependence. It can be therefore concluded based on this assertion that the results are robust to the changes in the frequency of the data, the number of selected lags, the choice of the decomposition method, etc.

An argument could be made that the results shown above can be criticised for lack of robustness alongside a few other dimensions. These critiques can be divided into the following list:

\section{Robustness of the method}

2. Choice of the sample period

3. ARCH effects

4. Model incompleteness, inclusion of the exchange rate as in the UIP condition (1)

5. Presence of structural breaks (inclusion of impulse saturation)

Upon considering the first argument, it is necessary to investigate whether the methodology is able to determine monetary independence correctly. In other words, it is necessary to check whether the chosen methodology allows discriminating between a significant relationship among interest rates in a pair of currency areas that are integrated and lack of such a relationship in the case of two non-integrated currency areas. In that way, as robustness checks the same methodology was used to examine the relationship between Wibor and USD Libor rate. At the outset, it was expected that the dependence of Polish interest rates on the Libor is smaller than the dependence on Euribor. To verify the hypothesis, the same VECM methodology was applied to Wibor and Libor three-month interbank interest rates. The model specification was selected using the same procedure as the model of Wibor and Euribor. The results of modelling of Wibor and Libor pair are shown in Tables 6 and 7 in Appendix. Cointegration tests show no significant relationship between these rates. Moreover, in calculating VECM the Libor terms are insignificant in the cointegrating equation. The 
variance decomposition exercise shows that there was no relationship between Libor and Wibor, which would allow us to refer to it as any type of dependence in monetary stance between these monetary areas. This allows us to argue that the methodology correctly permits discriminating between dependence and independence in domestic monetary policy.

The second potential critique may concern the choice of the study period. The analysed sample starts in the first months after the floatation of the zloty when the process of developing the long-term relationship between the interest rates had only just begun. This problem is illustrated by the plot of the residuals from the cointegrating relationship; in the initial period, the postulated relationship was only developing. It seems that this adjustment took the form of an adjustment on the side of the exchange rate because before the flotation the zloty was probably considerably overvalued. It can therefore be presumed that the inclusion of 2001-2002 period could potentially bias the results. This type of bias would lead to underestimation of the lack of freedom of monetary policy, i.e., it is on the "safe" side of the main hypothesis. To test the robustness of the results to the choice of the study period, the same methodology was applied for the following periods: 2003-2014, 2004-2014, 2005-2014 and 2006-2014. In each case, the obtained Johansen test results clearly indicated cointegration.

A third possible weakness of the study may be observed in the phenomenon of variance clustering in daily data. It can be argued, however, that the Johansen trace test used in the study is robust to this phenomenon. In addition, the usage of the weekly and monthly frequency of the data undermines the ARCH effect.

Even though the proposed modelling approach in the article of interest rates alone is representative of the independence of monetary policy, the third potential criticism concerns the possibility of testing a model with incomplete specification. Indeed, according to the theory of uncovered interest rate parity, analysis of the relationship between interest rates in two countries should take into account changes in the nominal exchange rate. Following in the footsteps of many other empirical studies of monetary policy independence, the study included only interest rates. As Juselius (2007) explains, each existing cointegration vector relates to a long-term relationship that will be preserved in all of the more general specifications of the model. (This is called sectoral specific-to-general property.) Thus, the cointegrated vector autoregressive model framework allows the modelling of partial systems as long as the rank test outcome is valid, so any cointegrating vectors found in that system should be found in any enlarged system (Juselius 2007). Therefore, as explained in Reade and Volz (2010) making of an econometric model based on an established cointegrating relationship solely for the interest rates should transfer to more complex models involving these rates, e.g., models relating to interest rate parities taking into account the exchange rate, the output gap, inflation and other factors affecting the external balance of the country.

Although due to these properties of the VECM model, any omission of a variable should not significantly affect the obtained results, the problem was subject to additional robustness analysis. The most pronounced concept including these rates is the uncovered interest rate parity. In this theory, interest rates are defined as the price of assets that are subject to financial arbitrage by international investors. In this article, 
Table 5 Impulse saturated coefficients for Euribor in Wibor equation. Source: Own

\begin{tabular}{lllll}
\hline & Coefficient & SE & $T$ Stat & $P$ value \\
\hline Daily & 0.6959700 & 0.0118994 & 58.487987 & 0.0000000 \\
Weekly & 1.0727753 & 0.0407112 & 26.3508609 & 0.0000000 \\
Monthly & 0.6721297 & 0.0446633 & 15.0488319 & 0.0000000 \\
\hline
\end{tabular}

these rates are treated instead as a realisation of activities in the field of monetary policy due to possible criticism; the model included this additional variable in the deprecation rate of the euro against zloty to move the model into the uncovered interest rate parity. However, in order to test the robustness of the results to the omitted variable problem we incorporated the nominal exchange rate of euro against zloty into the model. The main results are presented in Appendix (Table 8). Overwhelmingly, the tests results allow to reject the hypothesis of three cointegrating equations and gave no grounds to reject the hypothesis of two cointegrating equations. In line with the postulated property of VECM models indicated in the article, the relationship between interest rates in Poland and the Eurozone was strengthened after taking into account the exchange rate model. These results suggest that the design of the baseline model is correct and there are no indications of testing a model with incomplete specification.

Lastly, another objection may be raised against the omission of dummy variables in the model, which would relate to specific phenomena in the money markets that took place during the analysed period. For instance, a large number of such variables were applied in studies by Cuaresma and Wojcik (2006) and Reade and Volz (2010). The presence of structural breaks can produce bimodal residual distributions (Johansen 1995). In order to check the sensitivity of the results to the existence of structural brakes, we have estimated model using the methodology presented in Doornik et al. (2013). In this methodology the number and location of potential structural brakes are endogenous in the sense that they are estimated from the data using step indicator algorithm and not arbitrarily determined. The results obtained using this approach are generally lower than in the original investigation as shown in Table 5. The impulse saturation method resulted in the Euribor parameters being similar for daily and monthly and comparably stronger for weekly data, pointing to a stronger reaction of the monetary authorities in Poland to the foreign interest rate. $^{5}$

The VECM approach set out in Juselius (2007) is predicated on ensuring that normality of the residuals exists; without it one cannot fully trust the test statistics that are produced (for example, the trace test for rank and subsequent likelihood ratio tests). Table 9 lists the results of the skewness and Shapiro-Wilk and Jarque-Bera normality tests. The test statistics for the Wibor equation indicate a symmetric distribution across all frequencies. In contrast, as indicated by the normality tests, outliers in the daily

\footnotetext{
5 For instance, Goczek (2015) analyses interbank data for Romania and attributes monetary overreaction to a disinflation period in the sample.
} 
and weekly data create fatter tails than would be supported by a normal distribution. However, for the sample sizes we are using the small albeit significant deviations from normal distribution should not substantially distort the size of Johansen test (Silvapulle and Podivinsky 2000). Nonetheless, the results based on monthly data can be considered fully robust.

\section{Conclusions}

The independence of monetary policy within the framework of liberalised international capital flows and the floating exchange rate regime is considered one of the most important objectives of open economy macroeconomics. In the context of monetary integration, the loss of independence in carrying out monetary policy is regarded as the single most serious cost of a country's accession into a common currency area. However, the insights from theoretical considerations suggest that the actual extent of the freedom to conduct monetary policy in a small open economy is significantly limited, even in the case of a floating exchange rate. It could be argued that small open economies such as Poland, fully integrated financially with a larger monetary area, do not lose monetary independence when they decide to enter a common currency area. This is because it is impossible to enjoy this independence while being so dependent on financial flows from the major financial area. The confirmation of the hypothesis of low monetary independence in Poland in the empirical model described in the paper allows us to make the case that joining the EMU would potentially have smaller costs than is usually argued because a country cannot lose something that it does not have.

It seems that even now due to increasing integration with the Eurozone Polish monetary policy is a reflection of the policy carried out by the ECB. The proposed model does not allow us to provide an exact explanation of these empirical results for the observed phenomenon. However, a few explanations can be discussed ex post in more detail. These explanations can be divided into exogenous and endogenous factors to the monetary policy conducted in Poland. The first endogenous reason for this correspondence is an increasing level of correlation between business cycles in Poland and Germany. In this sense, the established direct transmission of European interest rates can be thought of as a general result of the continuing process of integration of the small open economy cases by increasing trade and financial flows, as the endogenous optimal currency areas theory posits (Frankel and Rose 1998). This business cycle convergence is likely to grow with the increasing interdependence in trade and capital flows; therefore, the independence of monetary policy is likely to decrease further.

The second endogenous explanation for this relatively high level of correlation of monetary policy in the two areas is a simultaneous reaction of both the ECB and the NBP sides, to a common or global component of inflation. Under this justification, central banks of both areas simply react to common international shocks in prices. This allows us to argue not for interdependence of these policies, but rather point towards the symmetry of shocks in both monetary areas. However, this argument can be contrasted with the fact that the ECB always leads the change in the monetary policy 
and the NBP only follows. This result would support the view that the Eurozone as a key global player transmits its conditions onto small open economies, albeit with a lag.

Conversely, these results can point towards exogenous problems. First, the fear-offloating phenomenon in the Polish monetary policy, in which interest rate setting acts as a way to dampen exchange rate shocks, could be to blame for the apparent following of the ECB monetary stance. However, under this explanation the presented approach could understate the actual degree of monetary independence offered by the floating exchange rate regime because the Polish monetary authorities simply did not opt for making use of their monetary independence-whether due to the fear of floating or because the cycle at home and abroad happens to require very similar monetary policy stances. Second, it is worth mentioning the possibility of a fear-of-floating behaviour. The fact that central banks respond similarly to external shocks is an indication that they could actually not be behaving optimally as long as the shocks they face are local or asymmetric.

Future research should focus on discriminating between the explanations given above. Nevertheless, it is important to note that whatever the explanation, whether endogenous or exogenous in a positive sense, monetary policy in Poland seems to be dependent on ECB policy in an almost one-by-one fashion. Therefore, the costs of joining the EMU by Poland could be potentially smaller than was argued in the NBP (2009) report on costs and benefits of joining the EMU upon the a priori assumption of full monetary policy dependence.

Acknowledgements The article was prepared as a part of the project "Measuring monetary independence in the context of joining euro zone: evidence from the countries with derogation", funded by the National Science Center, granted by Decision No. 2013/09/D/HS4/01051.

Open Access This article is distributed under the terms of the Creative Commons Attribution 4.0 International License (http://creativecommons.org/licenses/by/4.0/), which permits unrestricted use, distribution, and reproduction in any medium, provided you give appropriate credit to the original author(s) and the source, provide a link to the Creative Commons license, and indicate if changes were made.

\section{Appendix}

See Tables 6, 7, 8 and 9. 


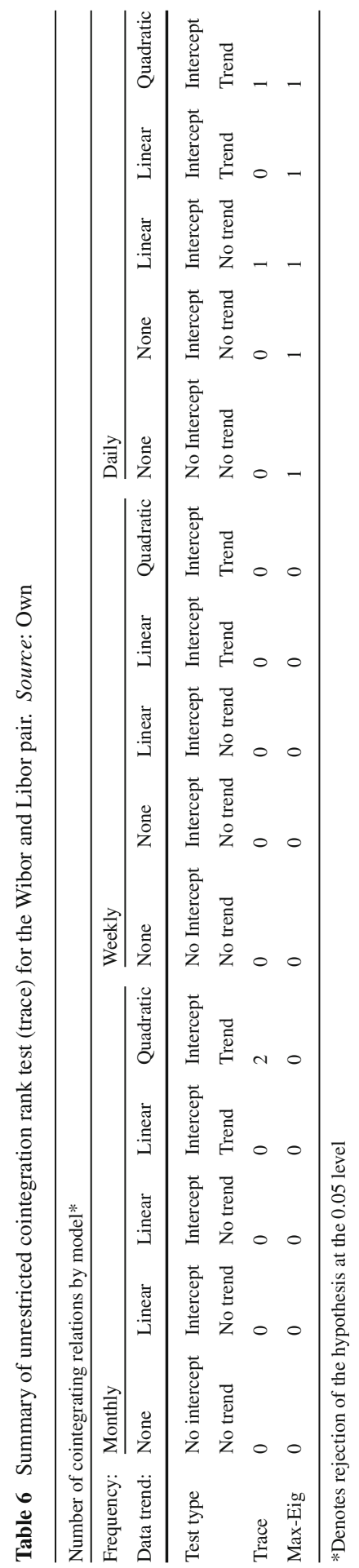




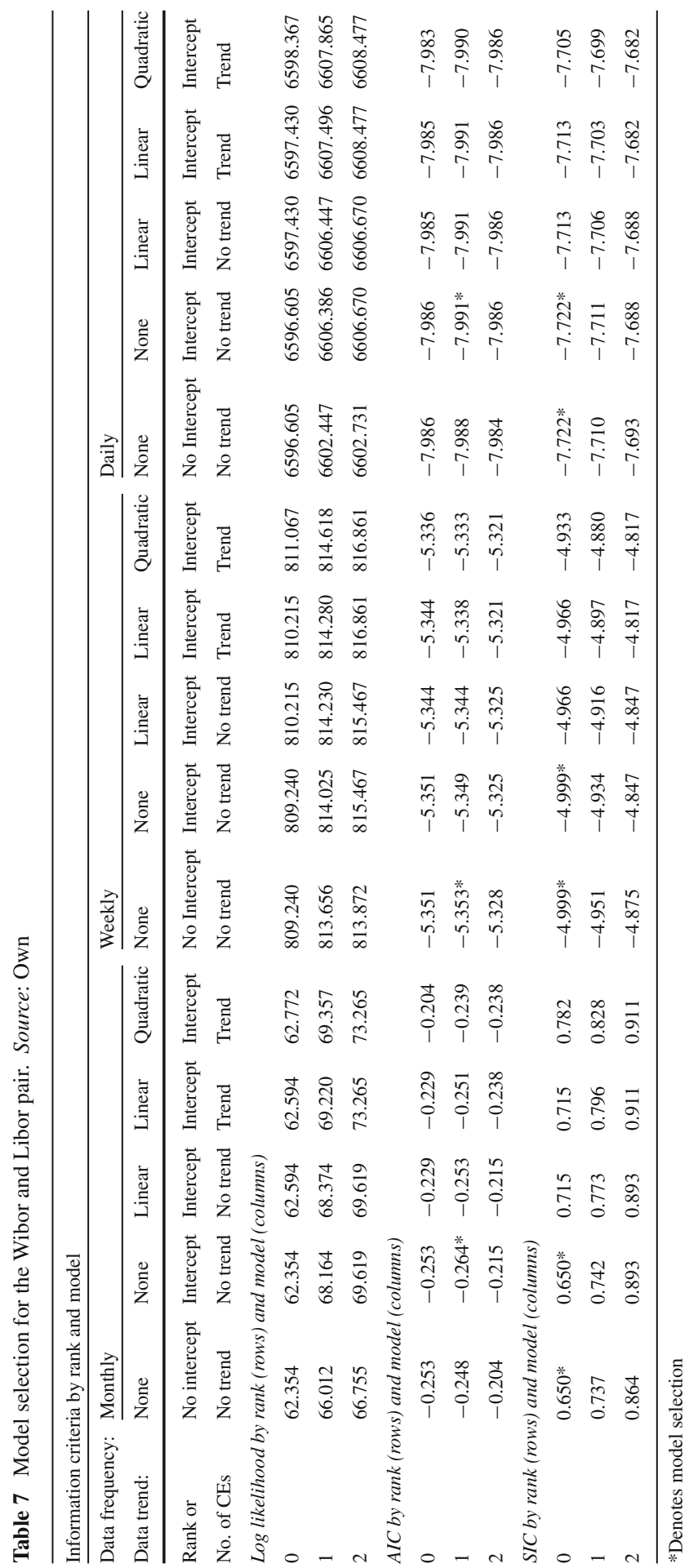




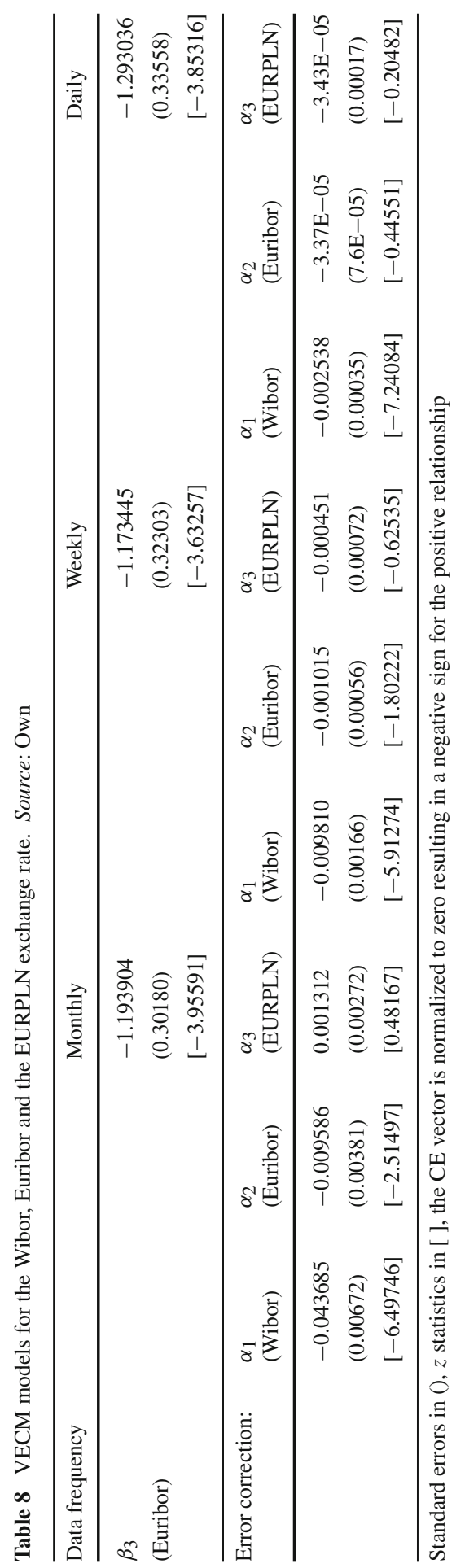


Table 9 Normality tests for the Wibor and Euribor pair. Source: Own

\begin{tabular}{|c|c|c|c|c|}
\hline & \multicolumn{2}{|c|}{ Wibor equation } & \multicolumn{2}{|c|}{ Euribor equation } \\
\hline & Statistic & $P$ value & Statistic & $P$ value \\
\hline \multicolumn{5}{|c|}{ Skewness test statistic } \\
\hline Daily & 9.551 & 0.998 & 21.342 & 1.000 \\
\hline Weekly & 0.051 & 0.178 & 35.825 & 1.000 \\
\hline Monthly & 1.006 & 0.684 & 0.592 & 0.558 \\
\hline \multicolumn{5}{|c|}{ Shapiro-Wilk normality test } \\
\hline Daily & 0.808 & 0.000 & 0.843 & 0.000 \\
\hline Weekly & 0.900 & 0.000 & 0.888 & 0.000 \\
\hline Monthly & 0.987 & 0.117 & 0.922 & 0.000 \\
\hline \multicolumn{5}{|c|}{ Jarque-Bera normality test } \\
\hline Daily & $14,432.510$ & 0.000 & $9,920.656$ & 0.000 \\
\hline Weekly & 897.217 & 0.000 & 871.924 & 0.000 \\
\hline Monthly & 2.270 & 0.321 & 72.345 & 0.000 \\
\hline
\end{tabular}

\section{References}

Aizenman J, Chinn MD, Ito H (2013) The "impossible trinity" hypothesis in an era of global imbalances: measurement and testing. Rev Int Econ 21(3):447-458

Ball CP, Reyes J (2008) Inflation targeting or fear of floating in disguise? A broader perspective. J Macroecon 30:308-326

Baranowski P, Gajewski P (2015) Credible enough? Forward guidance and perceived National Bank of Poland's policy rule, No 2/2015, Lodz Economics Working Papers

Bernanke B, Blinder A (1992) The federal funds rate and the channels of monetary transmission. Am Econ Rev 82(4):901-921

Buscher HS, Gabrisch H (2011) What Might Central Banks Lose or Gain in case of Euro Adoption-A GARCH-Analysis of Money Market Rates for Sweden, Denmark and the UK. In: IWH discussion papers

Cuaresma CJ, Wojcik C (2006) Measuring monetary independence: evidence from a group of new EU member countries. J Comp Econ 34(1):24-43

D’Adamo G (2009) Measuring exchange rate flexibility in Europe. In: MPRA Paper 26612

D'Adamo G (2010) Estimating Central Bank preferences in a small open economy: Sweden 1995-2009. In: MPRA Paper 26575

di Giovanni J, Shambaugh JC (2008) The impact of foreign interest rates on the economy: the role of the exchange rate regime. $\mathrm{J}$ Int Econ 74(2):341-361

Doornik JA, Hendry DF, Pretis F (2013) Step-indicator saturation. University of Oxford, Department of Economics Discussion Paper Series 658

Edwards S (2015) Monetary policy independence under flexible exchange rates: an Illusion? In: NBER working papers 20893, National Bureau of Economic Research, Inc

Ehrmann M, Fratzscher M (2002) Interdependence between the euro area and the US: what role for EMU? European Central Bank Working Paper Series, 200

Frankel J (1999) No single currency regime is right for all countries or at all times. In: NBER working papers 7338

Frankel J, Rose A (1998) The endogeneity of the optimum currency area criteria. Econ J 108(449):10091025

Frankel J, Schmukler S, Serven L (2004) Global transmission of interest rates: monetary independence and currency regime. J Int Money Finance 23(5):701-733

Goczek L (2015) Disinflation and monetary independence in Romania. Baltic J Econ 15(1):65-79

Goczek L, Mycielska D (2016) Euro Dominance hypothesis and monetary policy independence-The Czech Perspective, Prague Economic Papers, University of Economics, Prague, 2016(6): 655-670 
Gradzewicz M, Makarski K (2009) The welfare cost of monetary policy loss after the euro adoption in Poland. In: Report on full membership of the Republic of Poland in the third stage of the Economic and Monetary Union, National Bank of Poland, Warsaw

Hausmann R, Panizza U, Stein E (2001) Why do countries float the way they float? J Dev Econ 66(2):387414

Hofmann B, Bogdanova B (2012) Taylor rules and monetary policy: a global great deviation? BIS Q Rev September: $37-49$

Johansen SJ (1995) Likelihood-based inference in cointegrated vector autoregressive models. Advanced texts in econometrics. Oxford University Press, Oxford

Juselius K (2007) The cointegrated VAR model: methodology and applications, advanced texts in econometrics. Oxford University Press, Oxford

Klein M, Shambaugh J (2013) Rounding the corners of the policy trilemma: sources of monetary policy autonomy. In: NBER working papers 19461

Moon HR, Perron B (2007) An empirical analysis of nonstationarity in a panel of interest rates with factors. J Appl Econom 22(2):383-400

NBP (2009) Report on full membership of the Republic of Poland in the third stage of the Economic and Monetary Union. National Bank of Poland, Warsaw

Obstfeld M, Shambaugh J, Taylor A (2005) The trilemma in history: tradeoffs among exchange rates, monetary policies, and capital mobility. Rev Econ Stat 87(3):423-438

Reade J, Volz U (2011) Leader of the pack? German monetary dominance in Europe prior to EMU. Econ Model 28(1-2):239-250

Reade J, Volz U (2010) Too much to lose or more to gain? Should Sweden join the Euro? University of Birmingham Discussion Papers, 10-13

Rey H (2016) International channels of transmission of monetary policy and the Mundellian Trilemma. In: NBER Working Papers 21852, National Bureau of Economic Research, Inc

Silvapulle PS, Podivinsky JM (2000) The effect of non-normal disturbances and conditional heteroscedasticity on multiple cointegrated tests. J Stat Comput Simul 65(2):173-189

Taylor JB (2007) Globalization and monetary policy: missions impossible. In: Gertler M, Gali J (eds) The international dimensions of monetary policy. In: NBER conference, Girona, University of Chicago Press, pp 609-624

van Dijk D, Munandar H, Hafner C (2011) The euro introduction and noneuro currencies. Taylor Francis J 21(1-2):95-116

Windberger T, Cuaresma CJ, Walde J (2012) Dirty floating and monetary independence in Central and Eastern Europe: the role of structural breaks. In: University of Innsbruck, Faculty of Economics and Statistics Working Papers 2012-21 